\title{
Formation of a metamorphosis check in otoliths of the amphidromous goby Sicyopterus japonicus
}

\author{
Kang-Ning Shen, Wann-Nian Tzeng* \\ Department of Zoology, College of Science, National Taiwan University, Taipei, Taiwan 106, ROC
}

\begin{abstract}
A metamorphosis check $(\mathrm{MC})$ is a protein-rich, slow growth zone in fish otoliths. It has been proposed that deposition of this structure occurs during life history transitions, usually during migration from marine to freshwater habitats. To clarify MC deposition in relation to habitat shift and ontogenetic change of the amphidromous goby Sicyopterus japonicus, otolith microstructure, microchemistry $(\mathrm{Sr} / \mathrm{Ca}$ ) and morphological changes were examined across ontogenetic stages (larval, postlarval, juvenile, and adult) and environments (estuarine and a freshwater stream). The otolith $\mathrm{Sr} / \mathrm{Ca}$ ratios were higher in the estuary than in the stream environment. The MC was not found in otoliths until the fish metamorphosed from larvae to juveniles, indicating that it was deposited at the juvenile stage after migration from seawater to the freshwater habitat. The deposition of the check was concomitant with a change in head morphology associated with a transition in feeding behavior. Metamorphosis checks in otoliths provide further evidence of the usefulness of daily growth increments in reconstructing the early life history of diadromous fishes.
\end{abstract}

KEY WORDS: Amphidromous fishes · Goby · Metamorphosis check $\cdot$ Otolith $\cdot$ Sr/Ca ratios $\cdot$ Morphology

\section{INTRODUCTION}

Otoliths are located in the membranous labyrinth of the inner ear of teleost fishes (Lowenstein 1971). They are composed of aragonitic calcium carbonate in an organic matrix (Carlstrom 1963, Degens et al. 1969). The otolith undergoes accretionary growth, and is deposited on a daily basis (Simkiss 1974). Since Pannella (1971) discovered daily growth increments in otoliths, the ageing of fishes on a daily basis has been employed to reconstruct their early life history. A metamorphosis check (MC) is a slow-growth zone in fish otoliths, which is usually deposited during a life history transition of the fish. Most coral reef fishes deposit a MC at settlement, when they undergo the transition from pelagic larva to benthic postlarva. Therefore, the daily growth increments associated with the MC have been widely used to identify events in the early life history of reef fishes (Victor 1986, Wellington \& Victor 1989) and eels (Tzeng 1990, Tzeng \& Tsai 1994, Arai et al. 1997).

\footnotetext{
*Corresponding author. E-mail: wnt@ccms.ntu.edu.tw
}

Recent studies have indicated that variations in the $\mathrm{Sr} / \mathrm{Ca}$ ratio in otoliths can reveal the migratory environmental history of diadromous fishes (Radtke et al. 1988, Kalish 1990, Radtke \& Kinzie 1996, Tzeng et al. 1997). The ionic radius of strontium ( $\mathrm{Sr}$ ) is similar to that of calcium, allowing calcium in the aragonitic otolith to be substituted by $\mathrm{Sr}$ (Amiel et al. 1973). Strontium concentrations are 1 to 2 orders higher in seawater than in freshwater (Radtke et al. 1988, Campana 1999), and the $\mathrm{Sr} / \mathrm{Ca}$ ratio in otoliths are positively correlated with the salinity of the ambient water (Gallahar \& Kingsford 1996, Tzeng 1996). Thus, the $\mathrm{Sr} / \mathrm{Ca}$ ratios associated with daily growth increments in otoliths can be used to determine when a fish migrated from seawater to freshwater, e.g. for salmon (Kalish 1990), striped bass (Secor 1992), American shad (Limburg 1995) and American, European and Japanese eels (Tzeng \& Tsai 1994, Cheng \& Tzeng 1996, Tzeng et al. 1997, 1999, 2000, Wang \&Tzeng 1998, 2000). However, there are no studies linking the formation of the MC to changes in the $\mathrm{Sr} / \mathrm{Ca}$ ratio of otoliths of amphidromous gobiids. 
A previous study (Shen et al. 1998) revealed the presence of a MC in otoliths of many gobiids, e.g. Awaous melanocephalus, Eleotris acanthopoma, Oligolepis acutipennis, Redigobius bikolanus, Sicyopterus japonicus and Stenogobius genivittatus. The number of daily growth increments before the MC differ among these amphidromous gobies, and increment width becomes wider after the MC (Shen et al. 1998). In addition, during migration from seawater to freshwater habitats, postlarval gobies undergo abrupt morphological changes, including changes in coloration and fin shape (Manacop 1953, Erdman 1961, 1986, Tomihama 1972, Lau 1973), as well as in mouth shape, jaw structure, and digestive system (Tomihama 1972), all of which lead to faster growth rates. However, the timing of the $\mathrm{MC}$ in relation to these morphological changes has not been clarified.

This study attempts to link the time of MC deposition to otolith microstructure and microchemistry (Sr/Ca), and morphological changes in the goby Sicyopterus japonicus during its upstream migration, and to determine the pathway and mechanism of MC deposition.

\section{MATERIALS AND METHODS}

Sicyopterus japonicus is an amphidromous goby found in freshwater streams (Myers 1949). Adults breed in freshwater, and after hatching their larvae are passively transported to more saline environments. Postlarvae return to freshwater approximately 6 mo after hatching (Shen et al. 1998). Newly recruited postlarvae found in the estuary are transparent, with few pigments on their body surface.

Gobies were collected by a stationary net from a tributary of the Shuang-Chi River, Long-Long Brook, and its adjacent estuary in northeastern Taiwan $\left(121^{\circ} 08^{\prime} \mathrm{E}\right.$, $25^{\circ} 02^{\prime} \mathrm{N}$ ), from November 1995 to December 1996. A total of 22 individuals, including marine larvae, newly recruited postlarvae, juveniles and adults, were randomly selected for otolith microstructure and/or microchemistry analysis ( $\mathrm{n}=19$ ), and for external morphology examination of head shape, mouth position, and jaw-opening patterns $(n=3)$. Total length was measured to the nearest $1.0 \mathrm{~mm}$. The largest pair of otoliths, the sagitta, were removed and air-dried, and the right otolith was embedded in petropoxy 154 (Palouse Petroproducts, USA). One otholith was ground in the frontal plane with a 1200-grit paper and $0.05 \mu \mathrm{m}$ alumina paste until the primordium was exposed. The others were ground in the sagittal plane. The age of the fish was estimated from the number of growth increments on the otolith; these were assumed to be deposited daily, as in other fishes (Pannella 1971).

Microstructural and microchemical analytical methods were similar to those of Tzeng (1990) and Tzeng \& Tsai (1994). The radii of the otoliths were measured from 4 different growth axes (anterior, dorsal, posterior, and ventral). Sr/Ca ratios were measured from the primordium to the otolith edge. The position of the MC was determined from the pattern of growth increments and the Sr/Ca ratio of the otoliths.

\section{RESULTS}

\section{Otolith growth rate}

An obvious check was found in the otoliths of juvenile Sicyopterus japonicus, but was not apparent in marine larvae or newly recruited postlarvae in the estuary (Fig. 1). Accordingly, this check was assumed to be deposited when the fish metamorphosed from the larval to juvenile stage, and is termed a metamorphosis check (MC). The characteristics of the check are: (1) The radius of the check differs among different axes; this is due to the asymmetrical growth of the otolith. Prior to the check, the radius was greatest in

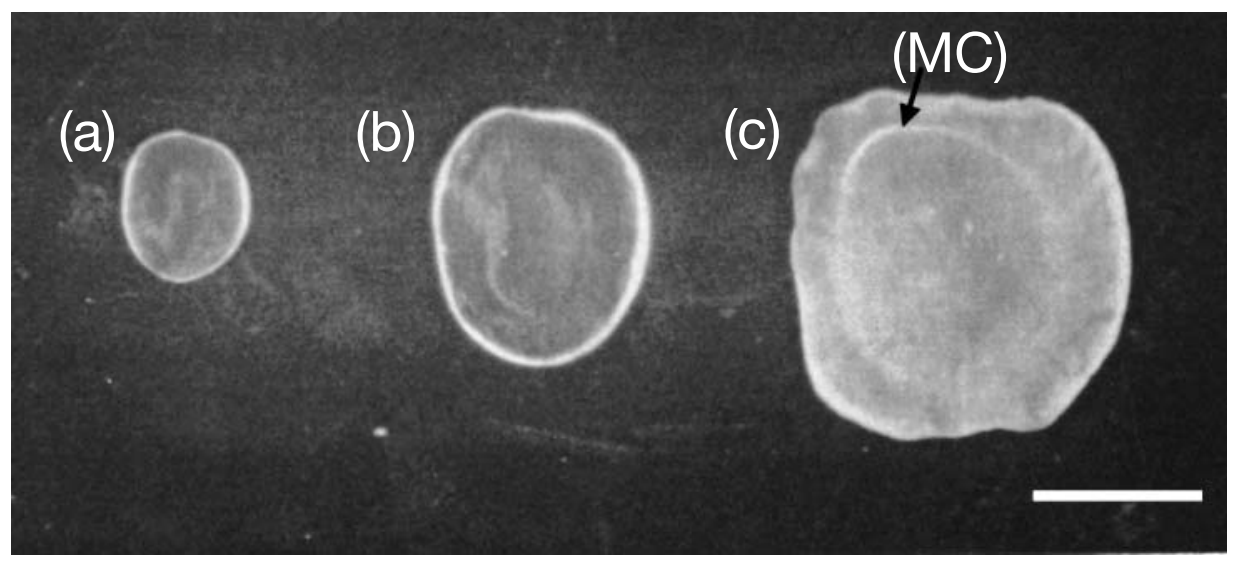

Fig. 1. Sicyopterus japonicus. Metamorphosis check (MC) in the otolith of a juvenile goby. Otoliths were photographed under a reflected light microscope. (a) Marine larva, $19 \mathrm{~mm}$ TL; (b) newly recruited postlarva in the Shuang-Chi River estuary, $34 \mathrm{~mm}$ total length (TL); (c) juvenile in freshwater of Long-Long Brook, $54 \mathrm{~mm}$ TL. MC was not found in (a) and (b), but is visible in (c). Scale bar $=5 \mu \mathrm{m}$ 
the posterior axis (Fig. 2); however, beyond the check, the radius of the distal axis was greater than that of the proximal axis (Fig. 2a) and the radius of the dorsal axis was greater than that of the other 3 axes (Fig. 2b). (2) In the lateral plane, the radii before the check were similar among individuals irrespective of total length (Fig. 3a), indicating that the fish metamorphose at a similar size, but beyond the check the otolith radius increased significantly with increasing fish size. The growth rate of the otolith was faster for the dorsal axis $\left(y=5.56 x-72.80, \mathrm{R}^{2}=0.6055\right)$ than for the other 3 axes $(y=3.28 x$ -56.30, $\mathrm{R}^{2}=0.8214$ : Fig. 3b). (3) The otolith increment widths before the check in the posterior axis were smaller and similar among individuals (mean $\pm \mathrm{SD}, 2.83 \pm 0.15 \mu \mathrm{m}, \mathrm{n}=3$ ), but varied after the check (4.9 \pm $1.4 \mu \mathrm{m}, \mathrm{n}=3$ ), indicating that the growth rate of the gobies is slower and almost homogenous in the marine larval stage and increases after metamorphosis.

\section{Otolith Sr/Ca ratios}

The mean $( \pm \mathrm{SD}) \mathrm{Sr} / \mathrm{Ca}$ ratios from the primordium to the edge of otoliths of 2 newly recruited postlarvae without a MC were $7.07 \pm 1.22 \times 10^{-3}$ and $7.46 \pm 1.00 \times 10^{-3}$, respectively. However, the $\mathrm{Sr} / \mathrm{Ca}$ ratios dramatically decreased after the $\mathrm{MC}$ in the otoliths of juveniles and adults, averaging $3.10 \pm 0.59 \times 10^{-3}(\mathrm{n}=4)$. The $\mathrm{MC}$ was deposited approximately 13 to 15 d (14.25 \pm 0.96 , $\mathrm{n}=4$ ) after the peak $\mathrm{Sr} / \mathrm{Ca}$ ratios in the otoliths. Fig. 4 shows the relationship between temporal changes in $\mathrm{Sr} / \mathrm{Ca}$ ratios and the deposition of the $\mathrm{MC}$ in the otolith of an adult goby. These results indicate that $\mathrm{Sr} / \mathrm{Ca}$ ratios in otoliths were higher in the marine larvae than in the juveniles and adults from freshwater, and that the MC was deposited approximately $2 \mathrm{wk}$ after migration of the larvae from marine to freshwater habitats. The deposition of the MC after the peak $\mathrm{Sr} / \mathrm{Ca}$ ratios in the otoliths may indicate that its deposition is more closely related to the physiological changes experienced by the fish than to the habitat change.

(b)
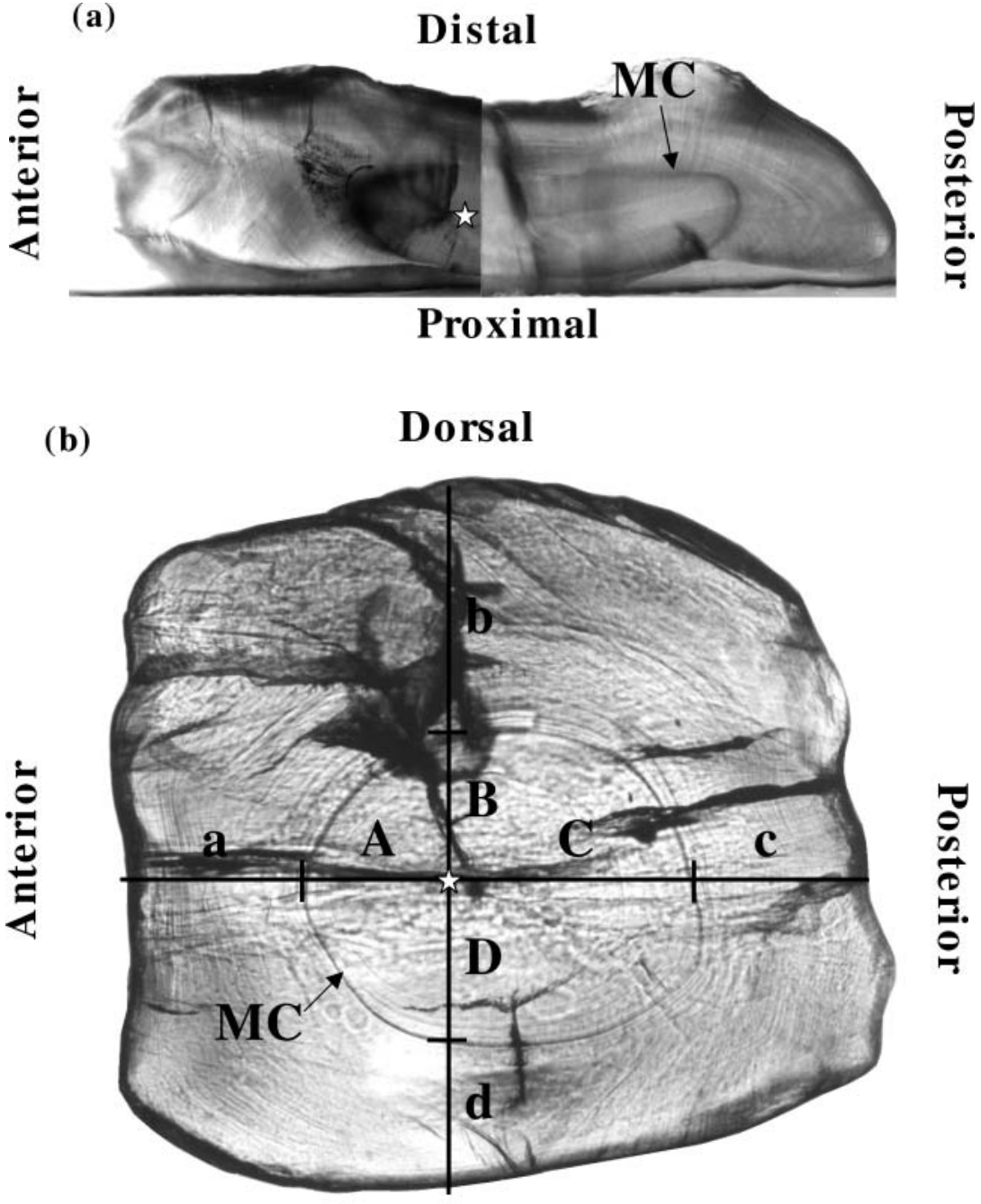

Ventral

Fig. 2. Sicyopterus japonicus. Structure of the sectioned otolith. (a) dorsal view; (b) lateral view. Short vertical lines crossing Axes A, B, C, D and a, b, c, d indicate

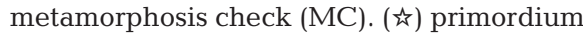

\section{Changes in mouth structure and otolith growth- increment pattern during upstream migration}

In the estuary, newly recruited postlarval gobies were transparent, with a terminal mouth (Fig. 5a). During growth to juveniles, the mouth position changed from terminal to subterminal, resulting from the change of head shape (Fig. 5b,c). Because no $\mathrm{MC}$ was found in otoliths of individuals with a terminal mouth, regardless of habitat (estuary or stream), the MC was assumed to be deposited as a result of physiological changes in association with mouth transformation that occurred after migration into the stream. 

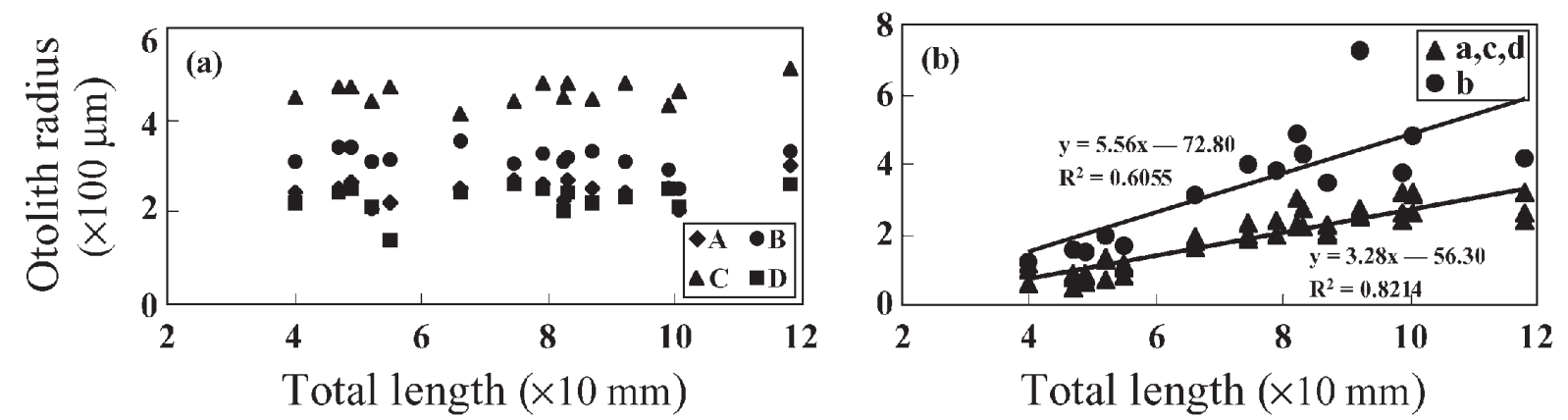

Fig. 3 Sicyopterus japonicus. Regression of otolith radius on total length. (a) Radii A-D from primordium to metamorphosis check (MC); (b) Radii a-d between MC and otolith edge (A-D and a-d as in Fig. 2b)

The pattern associated with daily growth increments also changed with the deposition of the MC. The otolith increments merged after the MC on the posterior axis (Fig. 6). This could lead to an age underestimation if growth increments are counted along the posterior axis of the otolith.
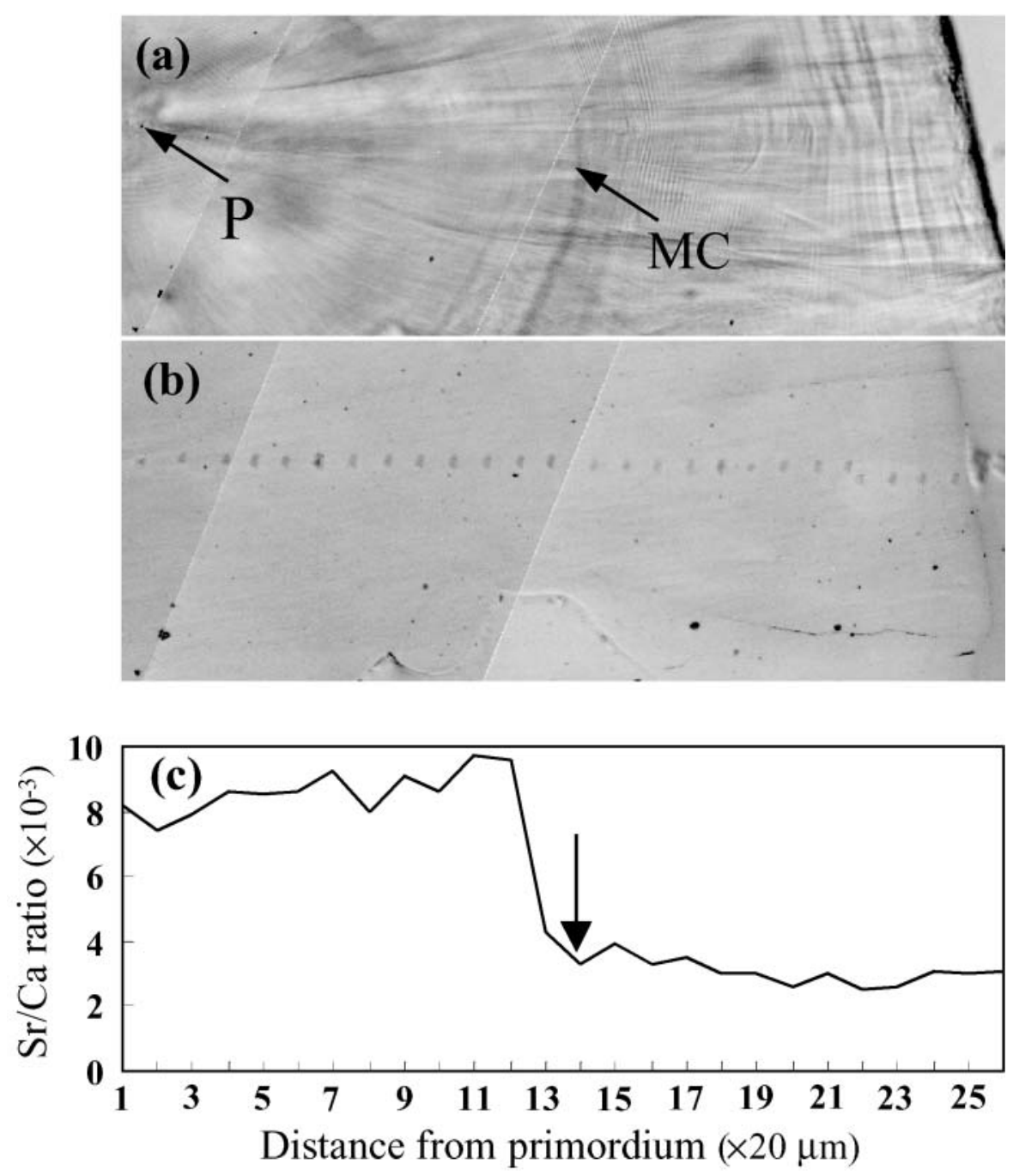

\section{DISCUSSION AND CONCLUSIONS}

The MC in the otoliths of the amphidromous goby Sicyopterus japonicus were deposited approximately 2 wk after Sr/Ca ratios dramatically decreased. The lag suggests that the deposition of MC was not directly caused by habitat transition (movement from seawater to freshwater), but was probably the result of a change in functional morphology associated with feeding behavior:

After MC deposition, otoliths grew faster on both the dorsal and distal axes. During this period, a simultaneous change in head structure, upper jaw, and mouth shape was observed. The depth of the head became higher and wider, while mouth shape changed from terminal to subterminal. The pattern of otolith growth increments also changed with these changes external morphology and

Fig. 4 Sicyopterus japonicus. Relationship between the temporal changes of $\mathrm{Sr} / \mathrm{Ca}$ ratios and the occurrence of metamorphosis check (MC) in otolith of a $79 \mathrm{~mm}$ TL adult $S$. japonicus collected in the freshwater region of Long-Long Brook on November 4, 1995. (a) Otolith section under transmitted light showing the position of the primordium (P) and $\mathrm{MC}_{\mathrm{i}}$ (b) otolith section with carbon coating showing the electron beam strike where $\mathrm{Sr} / \mathrm{Ca}$ ratios were measured, and (c) profile of $\mathrm{Sr} / \mathrm{Ca}$ ratios. Arrow indicates the position of $\mathrm{MC}$ 
Fig. 5. Sicyopterus japonicus. Head structure of individuals with different mouth shapes. (a) Terminal mouth, $34 \mathrm{~mm}$ total length (TL) postlarva collected from the Shuang-Chi River estuary; (b) intermediate phase, $33 \mathrm{~mm}$ TL juvenile collected from Long-Long Brook; (c) subterminal mouth, $33 \mathrm{~mm}$ TL juvenile collected from Long-Long Brook. Scale bars $=2 \mathrm{~mm}$

the subsequent formation of the MC. The morphological changes in the mouth structure of Sicyopterus japonicus were feeding adaptations enabling the shift from a marine planktivorous larva which feeds primarily on pelagic copepods, to an herbivorous postlarvae which grazes benthic algae from the stones in freshwater streams. This shift in the feeding regime contributed to increased growth of the fish, as indicated by the wider otolith increment after deposition of the MC.

Postlarval Sicyopterus japonicus migrating from the saline estuarine environment into a freshwater stream have to adapt to the salinity changes by regulating their osmotic pressure. Adaption to the new food resources available in freshwater streams is achieved by a transformation in mouth structure allowing grazing of benthic algae. These adaptive processes involve a high energy-demand. We presume that growth of postlarval gobies slows down during a regulatory and metamorphic process, and that the plasma normally available for otolith growth decreases, or is allocated to other processes. This is probably the reason why the growth increments around the MC were discontinuous and narrow.

A similar change in functional morphology during metamorphosis was also found for the Atlantic salmon Salmo salar, in which fin coloration and head shape change at the smolt stage during its migration from
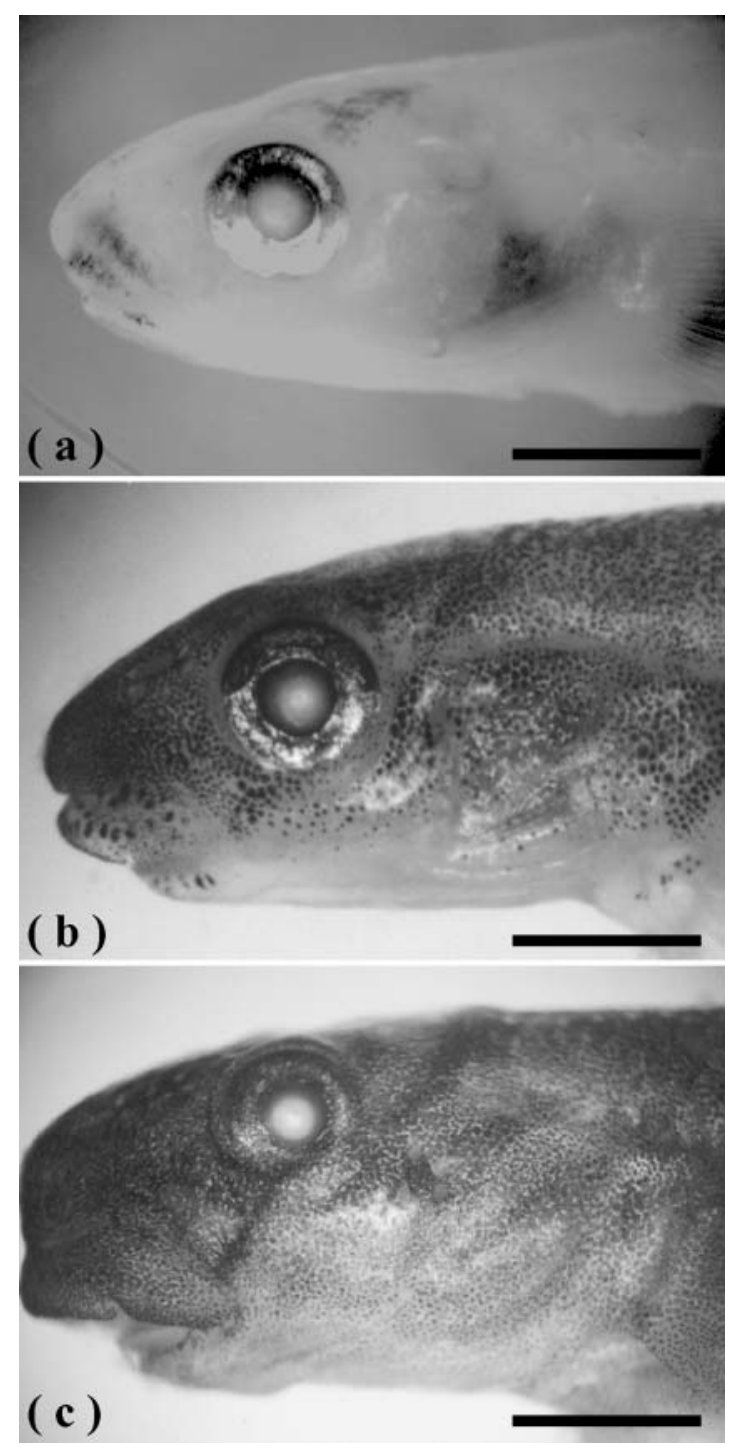

Fig. 6. Sicyopterus japonicus. Changing pattern of daily growth increments around metamorphosis check (MC) of the otolith of a $74 \mathrm{~mm} \mathrm{TL}$ adult. (1)-(4) Convergent process of growth increments. (a) is magnification of (b). A: anterior, D: dorsal, P: posterior, $\mathrm{V}$ : ventral

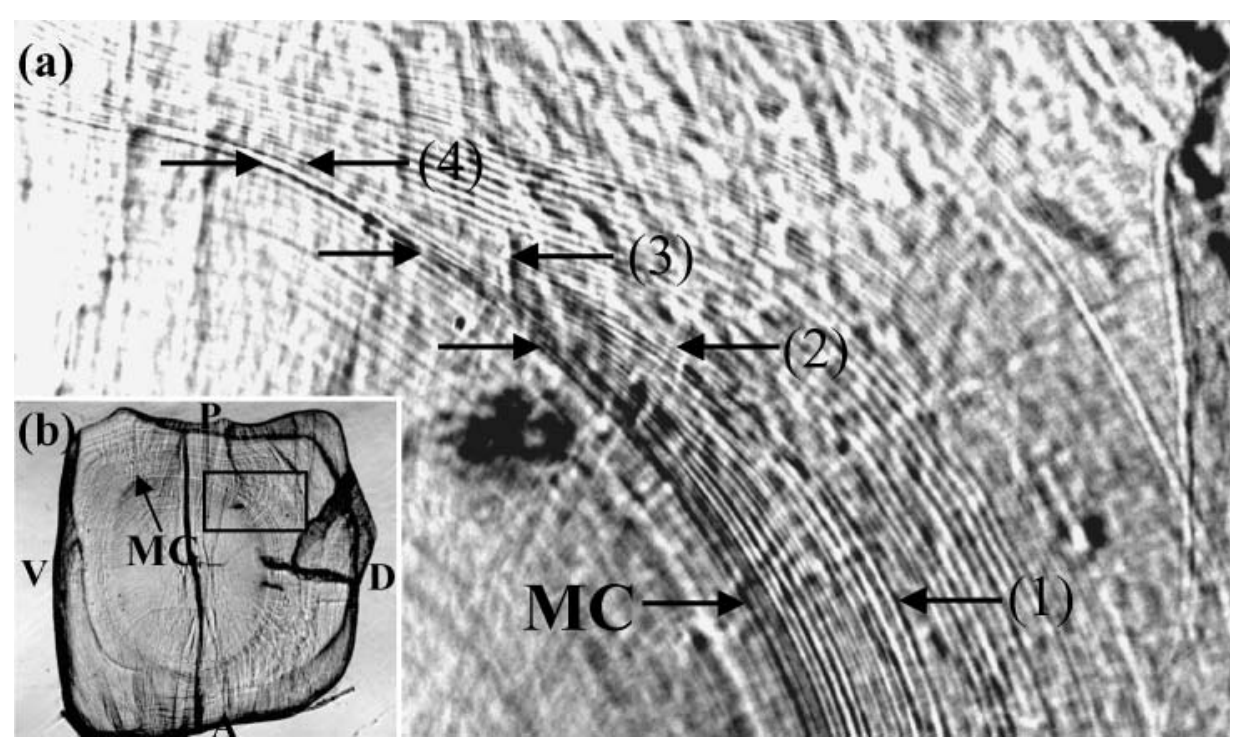


freshwater streams to the sea (McKeown 1984). The feeding habits of the salmon are changed and it shifts to a catabolic metabolism in response to changes in its internal environment during transition from the parr to the smolt stage (Wedemeyer et al. 1980). Salmon blood is rich in hormones, which have an osmoregulatory function during metamorphosis from the larval to postlarval stages. This may be one reason why the MC of the amphidromous goby is rich in protein. As reported by Zhang \& Runham (1992), the deposition of growth checks suggests that large amounts of protein are laid down during their formation, concomitant with either reduced calcium carbonate deposition or calcium resorption. When postlarvae complete metamorphosis and begin to feed, the calcium carbonate deposition rate of the otolith increases. In addition, the space in the inner ear on both the dorsal and proximal axes increases with the changes in head structure, allowing the otoliths to grow faster. In contrast, the limited space of the posterior axis of the otolith may cause interruptions in and convergence of growth increments. These observations indicate that $\mathrm{MC}$ deposition is influenced by both osmoregulatory hormones during the upstream migration of the gobies and by the changes in the head and upper jaw structures connected with changes in feeding habits. These processes appear to occur within a period of only a few days.

In conclusion, the MC in otoliths of the goby Sicyopterus japonicus are deposited at the juvenile stage, during migration from the sea to freshwater streams. The check reveals the time of this ontogenetic change and of the shift in feeding habits, both of which factors contribute greatly to a reconstruction of the gobies' early life history through otolith microstructural and microchemical analyses.

Acknowledgements. This study was conducted with the financial support of the National Science Foundation, Republic of China (Project No. NSC 89-2611-B002-004). The authors are grateful to Dr C. H. Chen of the Department of Geology, National Taiwan University, for helping with WDX analysis, and to Miss Jennifer M. Martin of the Department of Ecology and Evolutionary Biology, University of Connecticut, USA, for reading the English text.

\section{LITERATURE CITED}

Amiel AJ, Friedman GM, Miller DS (1973) Distribution and nature of incorporation of trace elements in modern aragonite corals. Sedimentology 20:47-64

Arai T, Otake T, Tsukamoto K (1997) Drastic changes in otolith microstructure and microchemistry accompanying the onset of metamorphosis in the Japanese eel Anguilla japonica. Mar Ecol Prog Ser 161:17-22

Campana SE (1999) Chemistry and composition of fish otoliths: pathways, mechanisms and applications. Mar Ecol Prog Ser 188:263-297
Carlstrom D (1963) A crystallographic study of vertebrate otoliths. Biol Bull (Woods Hole) 125:441-463

Cheng PW, Tzeng WN (1996) Timing of metamorphosis and estuarine arrival across the dispersal range of the Japanese eel Anguilla japonica. Mar Ecol Prog Ser 131:87-96

Degens ET, Deuser WG, Haedrich RL (1969) Molecular structure and composition of fish otoliths. Mar Biol 2:105-113

Erdman DS (1961) Notes on the biology of gobiid fish Sicydium plumieri in Puerto Rico. Bull Mar Sci Gulf Caribbean 11:448-456

Erdman DS (1986) The green stream goby, Sicydium plumieri, in Puerto Rico. Trop Fish Hobbyist 2:70-74

Gallahar NK, Kingsford MJ (1996) Factors influencing Sr/Ca ratios in otolith of Girella elevata: an experimental investigation. J Fish Biol 48:174-186

Kalish JM (1990) Use of otolith microchemistry to distinguish the progeny of sympatric anadromous and non-anadromous salmonids. Fish Bull 88:657-666

Lau ETK (1973) Dimorphism and speciation in the Hawaiian freshwater goby genus Lentipes. MS thesis, Department of Zoology, University of Hawaii, Honolulu

Limburg KE (1995) Otolith strontium traces environmental history of subyearling American shad Alosa sapidissima. Mar Ecol Prog Ser 119:25-35

Lowenstein O (1971) The labyrinth. In: Hoar WS, Randall DJ (eds) Fish physiology, Vol. 5. Academic Press, New York, p 207-240

Manacop PR (1953) The life history and habits of the goby, Sicyopterus extraneus Herre (Anga) Gobiidae, with an account of the goby-fry fishery of Cagayan River, Oriental Misamis. Philipp J Fish 2:1-7

McKeown BA (1984) Fish migration. Croon Helm, London

Myers GS (1949) Usage of anadromous, catadromous and allied terms for migratory fishes. Copeia 1949:89-97

Pannella G (1971) Fish otoliths: daily growth layers and periodical patterns. Science 173:1124-1127

Radtke RL, Kinzie RA III (1996) Evidence of a marine larval stage in endemic Hawaiian stream gobies isolated from high-elevation locations. Trans Am Fish Soc 125:613-621

Radtke RL, Kinzie RA III, Folsom SD (1988) Age at recruitment of Hawaiian freshwater gobies. Environ Biol Fish 23(3):205-213

Secor DH (1992) Application of otolith microchemistry analysis to investigate anadromy in Chesapeake Bay striped bass Morone saxatilis. Fish Bull 90:798-806

Shen KN, Lee YC, Tzeng WN (1998) Use of otolith microchemistry to investigate the life history pattern of gobies in a Taiwanese stream. Zool Stud 37:322-329

Simkiss K (1974) Calcium metabolism of the fish in relation to aging. In: Bagenal TB (ed) Aging of Fish. Unwin Brothers, Old Working, UK, p 1-12

Tomihama MT (1972) The biology of Sicydium stimpsoni: freshwater goby endemic to Hawaii. BS (Honors) thesis; Department of Zoology, University of Hawaii, Honolulu

Tzeng WN (1990) Relationship between growth rate and age at recruitment of Anguilla japonica elvers in the Taiwan estuary as inferred from otolith growth increment. Mar Biol 107:75-81

Tzeng WN (1996) Effects of salinity and ontogenetic movement on strontium: calcium ratio in otolith of the Japanese eel, Anguilla japonica Temminck \& Schlegel. J Exp Mar Biol Ecol 199:111-122

Tzeng WN, Tsai YC (1994) Changes in otolith microchemistry of the Japanese eel, Anguilla japonica, during its migration from the ocean to the rivers of Taiwan. J Fish Biol 45:671-683

Tzeng WN, Severin KP, Wickström H (1997) Use of otolith 
microchemistry to investigate the environmental history of European eel Anguilla anguilla. Mar Ecol Prog Ser 149: 73-81

Tzeng WN, Severin KP, Wickström H, Wang CH (1999) Strontium bands in relation to age marks in otoliths of European eel Anguilla anguilla. Zool Stud 38:452-457

Tzeng WN, Wang CH, Wickström H, Reizenstein M (2000) Occurrence of the semi-catadromous European eel Anguilla anguilla in the Baltic Sea. Mar Biol 137:93-98

Victor BC (1986) Duration of the planktonic larval stage of one hundred species of Pacific and Atlantic wrasses (family Labridae). Mar Biol 90:317-326

Wang $\mathrm{CH}$, Tzeng WN (1998) Interpretation of geographic variation in size of American eel Anguilla rostrata elvers on the Atlantic coast of North American using their life

Editorial responsibility: Otto Kinne (Editor), Oldendorf/Luhe, Germany history and otolith ageing. Mar Ecol Prog Ser 168:35-43

Wang $\mathrm{CH}$, Tzeng WN (2000) The timing of metamorphosis and growth rates of American and European eel leptocephali: a mechanism of larval segregative migration. Fish Res (Amst) 46:191-205

Wedemeyer GA, Saunders RL, Clarke WC (1980) Environmental factors affecting smoltification and early sea water survival of anadromous salmonids. Mar Fish Rev $6: 1-14$

Wellington GM, Victor BC (1989) Planktonic larval duration of one hundred species of Pacific and Atlantic damselfishes (Pomacentridae). Mar Biol 101:557-567

Zhang Z, Runham NW (1992) Temporal deposition of incremental and discontinuous zones in the otoliths of Oreochromis niloticus (L.). J Fish Biol 40:333-340

Submitted: July 18, 2000; Accepted: April 5, 2001

Proofs received from author(s): February 6, 2002 